Open Access

\title{
Differentiation strategies for the wine and nursery sector: empirical evidence from an Italy region
}

Piermichele La Sala ${ }^{1 *}$ (D), Raffaele Silvestri ${ }^{2}$ and Francesco Contò ${ }^{1}$

\author{
* Correspondence: \\ piermichele.lasala@unifig.it \\ ${ }^{1}$ Department of Economics, \\ University of Foggia, Largo Papa \\ Giovanni Paolo II n. 1, 71122 Foggia, \\ Italy \\ Full list of author information is \\ available at the end of the article
}

\begin{abstract}
The aim of the paper is to analyze how the dynamic capabilities of the wine industry actors, involved in searching for biodiversity, influence and are influenced by the dyadic buyer-supplier relationship. In particular, the study aims at analyzing how the organizational culture, the strategic and relational approach, adopted in the customer-supplier interactions, affect the inter-organizational learning and the value-creating process. For this purpose, an explorative study has been carried out in the wine supply chain of Basilicata region (in southern Italy). Data are collected by submitting a semi-structured interview to the complete population of wineries and grape growers in the abovementioned area. By means of Principal Component Analysis and a Spearman's rank correlation analysis, the paper investigates if the relational approach adopted by the winery toward the grape grower affects positively the dynamic capabilities for wine differentiation strategies.

Results show the grape grower are positively influenced by an organizational culture of winemakers based on flexibility and not standardized transformation processes then facilitating the planting choices and assuring the health of cuttings.
\end{abstract}

Keywords: Dynamic capabilities, Customer value, Wine supply network, Buyer-supplier relationship, Inter-firm learning

\section{Background}

A strong and durable competitive advantage in the wine industry can be searched for in exploiting the "terroir" and the biodiversity of the vine grape, which can result in unique and recognizable organoleptic scents. Those sensorial elements bind inseparably the taste of a wine to a unique grape-growing area, thus becoming a source of distinctness almost unbeatable, to the extent that it is supported by appropriate communication and brand management policies.

The research of biodiversity is a process of knowledge development, both the existing and the new one, about the soil and the grape, from the technical production point of view, and about the sensorial needs of the target market, from a commercial point of view.

This process is carried out by identifying, attracting, and reconfiguring the knowledge about the grape biodiversity: it is an information flow management, both internal and external the firm boundaries, together with the relevant supply network's actors, such as biological analysis laboratories, research institutes, and grape growers. The

(c) The Author(s). 2017 Open Access This article is distributed under the terms of the Creative Commons Attribution 4.0 International License (http://creativecommons.org/licenses/by/4.0/), which permits unrestricted use, distribution, and reproduction in any medium, provided you give appropriate credit to the original author(s) and the source, provide a link to the Creative Commons license, and indicate if changes were made. 
dynamic capabilities can support this process; on the other hand, the information flow with external actors is managed through relationships.

For this reasons, the purpose of the paper is to analyze how the winery's dynamic capabilities, needed to exploit the biodiversity, are influenced by the dyadic relationship with the grape grower, in particular by some specific features regarding the organizational culture and the relational approach.

The dynamic capabilities allow the firm to recognize the changing environment and, placing between business and environment, enable firm resources to dynamically adapt to changing environmental characteristics (Teece et al. 1997). According to the competence-based view (Teece et al. 1997), the innovative behavior of some companies aimed at finding distinctive features from their competitors, which can generate a differentiation strategy, arises from the ability to introduce continuously product and process innovations. In dynamic and high-intensity competition contexts, the dynamic behavior can be explained if the business holds skills with equally dynamic nature.

Organizations, and new governance mechanisms are taking place more and more in the field of innovation and valorisation of the agri-food sector (Cembalo 2015); the agri-food chain performances are affected by the way the stakeholders are involved in the chains and by the way of coordinating the relationships among the actors (Carbone 2017).

The relational approach (Håkansson and Ford 2002) analyzes the dynamic capabilities of the actors in the wine supply network involved in seeking for biodiversity, by means of studying the concepts of strategic orientation, relational approach, and inter-firm learning within a network system of relationships (Silvestri et al. 2016; Contò et al. 2016). Some authors highlighted the relevant role of a relational perspective on the management of wine tourism systems, underlining the necessity for the development of boards, networks, constellations, and flows (Festa et al. 2015; Georgiou and Vrontis 2013).

In this network, several actors are involved, such as the wineries and the grape growers, which allow the firm to attract and to share the resources needed to survive (Fiocca 2014). The approach based on the analysis of the relationships between firms is relatively recent in the studies of the wine industry. However, the agricultural economist is trying to expand the study on the supply chain to the analysis of relationships between the companies in this sector, borrowing methods from different economic sectors (Cafaggi and Iamiceli 2010). The paper focuses on the abovementioned features, as enablers of the dynamic capabilities in buyer-supplier relationships, which can influence the knowledge transfer among businesses within a dyadic buyer-supplier relationship.

Then, originality of this paper can be found in the new field of investigating in the wine sector: far from being exhaustive, it can shed some light on this topic, since there are few studies regarding the role of the dyadic buyer-supplier relationship.

The remainder of this paper is as follows: after the definition of the theoretical framework and hypothesis, materials and methods are presented in detail by defining the investigated sector, the data collection, and the measures validation. Then, the results are shown and discussed; the conclusions section gives insight by drawing implications for researchers and practitioners. 


\section{Theoretical background and hypotheses}

Management studies have several theoretical approaches that are not in conflict with each other but tend to converge and complete: this is certainly the case for the convergence between the dynamic capabilities and the network theories.

The first one derives from the studies of Itami and Roehl (1987) which identify in the invisible asset mobilization, one of the ways for achieving the competitive advantage; on the other hand, most of the resources, which build the abovementioned invisible asset, are not those the firm already has but those which lie in the context in which they work.

In this perspective, the ability to attract the external resources, to put them into their intangible assets, generates a distinctive high-level competence, often superior to any other distinctive competency in the company (Barney 1991). The intangible resources can be distinguished in knowledge and trust resources: the former support the firm development by continuously generating new knowledge, acting on people's involvement, on the firm culture and identity; the second, generate and consolidate the company's position on the market and produce economically appreciable consequences such as customer loyalty and customer retention.

From this assumption, it arises the firm needs to identify the external relevant resources, to attract and to reconfigure them, within the operating structure, into new distinctive knowledge.

Therefore, the relationships represent the way of connecting with external actors that have significant resources for the firm and the attraction vector of such resources within the firm. Thus, the firm's ability to achieve and to keep the competitive advantage is strongly related to its position in the business network and to the capabilities of effective relationship management with the network's actors. For these reasons, the paper bases the analysis on different, even if complementary, theoretical approaches.

Competences are meant as a system based on knowledge (Grant 1996) made up of expertise and technical systems, the management system and the system of values in the role of creation and supervision of such knowledge (Teece et al. 1997; Leonard Barton 1992). Firm intangible resources and capabilities that dynamically enable organizations to adapt their resources to the evolution of the environment are an element of diversity among firms (Prahalad and Hamel 1990). The creation of value comes up from the effective use of dynamic capabilities, which depend fundamentally by three processes: learning, integration, and reconfiguration of resources. The skills have to be able to coordinate the business resources in order to finalize them in a coherent way for the competitive advantage achievement. They can be meant as integrated subsets of resources that allow the firm to realize distinctive activities. The resources, however, are firm-specific and show a more static nature: it is often appropriate to integrate them with external technological, financial, and marketing assets (Fuentes-Lombardo et al. 2014). The capability in integrating the external and internal assets has a dynamic nature since the market's evolution implies a continuous change of resources and ways of their using (Verona 2014).

The dynamic capabilities are based on very high levels of sensitivity, experience, and willingness to engage profoundly on the company's business. They allow resources to be not depleted in terms of value and ability to get a competitive advantage, not so much because of their inadequacy in absolute terms, as for the fact that environmental 
changes can reduce their effectiveness and hence make them no longer fit to support the firm in the relationship with the environment (sector / market) which in the meantime changes.

Supply chains with resources in disarray can also be a constraint on the achievement of food security and so affecting the availability and affordability of food (Revoredo-Giha and Renwick 2016). The dynamic capabilities should lead to the resource reconfiguration: this process assures the business management logic changing for a learning path that will allow wider evolution. The interaction with the actors in the belonging network affects and increases the dynamic capabilities, thus stimulating the management to break the interpretive schemes and the ritualization in decision-making and implementing process of a strategy able to face effectively the market complexity (Barile 2009). This distinctive skill system has an intrinsic form of endogenous inertia that can turn into equally distinctive rigidity (Leonard Barton 1992; Verona 2014). The generation of competitive advantage in dynamic contexts brings the skills to exercise constantly learning ability: the dynamic behavior of some wine firms is explicable with their ability to adopt a managerial logic of seeking for distinctive features concerning the technology and the market.

The research-starting assumption is that the interaction between the winery and the grape grower encloses a wide range of distinctive dynamic capabilities of both the players involved, from which can arise the biodiversity, the quality, and the most recognizable and inimitable elements of wine.

The identification of these dynamic capabilities and the understanding of the elements they are affected by can be useful in the decision-making process underlying the activities of research, development, and innovation aimed at biodiversity.

\section{Relational approach}

The enhancement of grape's biodiversity, interpreted according to the relational perspective, can be realized in the last phase of value creation process, by selling a certified high-quality wine: the grape's biodiversity gives added value to the consumer in sensorial and hedonistic terms, thus generating competitive advantage for the wineries of a specific area (Pinder 2011). The creating value based on biodiversity is a phased process in which knowledge circulates and is filtered and transferred by different actors of the network (winery, grape grower, research laboratories, etc.) through the exchange of resources and competencies. The starting point of this process lies in the relationship management between the upstream supply chain firms (wineries, grape growers, research institutes, other suppliers). The wineries' marketing strategy chances to achieve the consumer trust are enclosed in the ability of developing relationships in order to create the conditions to access to intangible resources of the other players in the network, to combine them harmoniously with their own, to occupy the most convenient location within the network, then to acquire a competitive advantage, which is defensible in the new economic environments due to globalization of markets (Contò et al. 2015; Stoddard and Clopton 2015; Tudisca et al. 2013).

Studies on the topic (Fiore et al., 2017; Vrontis et al. 2011; Vrontis and Papasolomou 2007) demonstrate that critical points in wineries are cultivation varieties, production methods, and know-how-related factors. A clear strategic path should forecast the product building, marketing strategies, focused targeting, differentiation, perception management-based branding, and country-of-origin image development. Resources are improved with the dynamic capabilities and, in turn, are the basis of the distinctive 
skills that are developed and activated with the relationships within the network (Fiocca 2014). From the relational point of view, any market structure is the result of a continuous flow of interaction and mutual adaptation between the actors which generates a complex network made up of actors and interdependencies between these resources and their activities. Some authors (Cantù et al. 2013) consider the economic relationships between the actors in the network not only in terms of competition, but also in terms of "business networking" in which companies compete in changing the structure of the network through a continuous interactive process.

The relationships within the networks have been developed to create a market differential (a concept that goes beyond the concepts of competitive advantage and key success factors), through the use of the resources of a business, that affects its location into a network.

Every business relationship has both elements of competition and cooperation. The competitive advantage can result from the cooperation with suppliers, customers, and other stakeholders, and cooperation can be a means of strengthening the position of an enterprise network, also gaining a higher position than its competitors (Cantù et al. 2013).

So we can suppose that the quality of wineries' offer can depend on the transfer abilities (each other buyer-supplier) at the research and development stage and on the problem solving abilities (Håkansson and Ford 2002) of suppliers in transforming those requirements into solution proposals.

The problem solving abilities is a central element for the wineries, that is, the interaction with grape growers able to identify and fully understand their needs, as well as to insert and translate those needs into their offerings quickly. The needs referred to in the relationship between the winery and nursery are primarily the phenotypic characteristics of the selected clones, the phonological elements, and the qualitative characters (yield of juice, sugar content, anthocyanin, polyphenols, then aroma particularity). The other needs are related to the production and logistic problems.

Regarding transfer abilities, wineries refer to the grape grower ability to convey new information for their customers. This ability is closely linked with sale managers' indepth knowledge of the winery production process enhanced by frequent visits and by joint research and development.

What, in the dyadic buyer-supplier relationship between the winery and the grape grower, affects the dynamic capabilities of wineries engaged in seeking biodiversity?

From the analysis of theoretical framework about the relational approach comes the hypothesis we intend to verify:

Hp1. The relational approach adopted by the winery toward the grape grower affects positively the problem solving and transfer abilities

\section{Strategic orientation}

According to eminent scholars, the strategic orientation is concerned with the decisions that businesses make to achieve superior performance: so, the strategic orientation defines the broad outlines for the firm's strategy (Slater et al. 2006). The strategy should allow the firm to connect and align with its target market. The strategic orientation is then interpretable as the way the firm is connected to the competitive environment and oriented to the market. 
There are several conceptualizations (Celuch et al. 2002) of market orientation in the literature, among which two main perspectives emerge: market orientation as culture (Narver and Slater 1990) and as behavior (Kohli and Jaworski 1990).

Narver and Slater (1990) define market orientation as the organizational culture that most effectively and efficiently creates the necessary behaviors for the creation of superior value for buyers and, thus, continuous superior performance for the business. They suggest that market orientation is expressed by three behavioral components: customer orientation, competitor orientation, and inter-functional coordination.

From the behavioral point of view, Kohli and Jaworski (1990) define market orientation as the organization of wide information acquisition, dissemination, and responsiveness to market intelligence.

From the cultural point of view (Khin et al. 2012; Conto et al. 2014), the concept of customer orientation highlights the importance of customer for the firms' performance in many aspects including new product development. Narver and Slater (1990) define customer orientation as the firm's sufficient understanding of its target buyers in order to be able to create superior value for them continuously.

According to several studies emerging by the literature (e.g., Hurley and Hult 1998; Paladino 2007; Theoharakis and Hooley 2008), there is a positive relationship between customer orientation and innovation and the latter has to be combined with tradition (Vrontis et al. 2016; Viassone et al. 2016): customer orientation affects positively innovation because a better understanding of customer needs by means of customer orientation allows the firms to offer new and superior products that satisfy customers.

The concept of competitor orientation, according to Narver and Slater (1990) is linked to the capacity of understanding the short-term strengths and weaknesses and long-term capabilities and strategies of key potential competitors. Some authors (Rossi et al. 2012) by means of a survey administrated to 180 Italian companies demonstrated it emerges the need to implement strategies towards achieving sustainable competitive advantage. Parallel to customer orientation, it emerges by the literature a significant relationship between competitor orientation and innovativeness (Hurley and Hult 1998; Augusto and Coelho 2009; Paladino 2007).

Within the theoretical framework on the concept of strategic orientation, we believe that

Hp2. A homogeneous organisational culture in strategic orientation (Narver and Slater 1990), meant as the common language and shared usual behaviour that facilitate the interaction (Camuffo and Grandinetti 2011), can positively affect the inter-firm learning, which represents one of the fundamental processes for the dynamic capabilities generation.

\section{Inter-firm learning}

The inter-firm learning concept is referred, in the academic literature, to the access and employ of critical information or capabilities from a business partner through collaboration (Kale et al. 2000). Some scholars analyzed the role of the strategic alliances on the inter-firm learning (Inkpen 2000; Kale et al. 2000; Simonin 2004). Some others focused on the role of the network relationships on knowledge sharing and transferring (Spekman et al. 2002; Dyer and Hatch 2004, 2006; Hult et al. 2004; Wagner and Buko 2005) and on the supplier's standpoint in getting new knowledge from the customer (Modi 
and Mabert 2007; Håkansson and Ford 2002). We did not find studies in the academic literature on the influence of the organizational culture on the inter-firm learning.

\section{Organizational culture}

There is a wide and intense academic debate on the organizational culture topic as it is considered crucial both for operational and strategic activities. In strategic terms, it is considered as drivers of competitive advantage (Xiaoming and Junchen 2012) since it affects the endogenous organizational development (Denison and Spreitzer 1991), the effectiveness of the operational structure (Gregory et al. 2009; Zheng et al. 2010), and the financial performance (Barney 1991).

The organizational culture can also become a driver of competitive advantage even in inter-organizational cooperation. (Noorderhaven et al. 2002; Wang and Li 2007; Xiao and Tsui 2007).

An organizational culture that promotes and facilitates the cooperation is important to establish inter-organizational relationships long-term: the cultural elements are relevant in the process of cooperation and co-creation of value (Kanter 1994; Laskowska-Rutkowska 2009). No previous research on the organizational culture influence on problem solving and transfer abilities within a buyer-supplier business relationship have been found. According to the Competing Values Framework, there are different models of organizational culture based on two independent dimensions: the structure and strategic focus (Gregory et al. 2009). The differences between the models can be identified by these two dimensions and identified according to the following cultural characteristics: strategy, flexibility/technology, organization, and management style (Morgan 2007). Depending on the preeminence of cultural characteristics, organizations show different organizational culture models. Basing on this theoretical background, we expect the organizational culture is positively associated with the inter-firm learning, thus also with problem solving and transfer abilities. Hence:

Hp3. The organizational culture is positively correlated with the Inter-Firm learning

Hp4. The organizational culture is positively correlated with the problem solving abilities

Hp5. The organizational culture is positively correlated with the Transfer Abilities

The paper analyzes, among the different elements that could affect the customer-supplier relationship, the strategic orientation as it represents a mental approach of the management and adopts both in formulating decisions and in managing interactions with the relevant actors.

A fundamental communication element for an effective knowledge exchange through the interaction is represented by a common meta-language that facilitates this information flow.

For this reason, it seems helpful to analyze how the elements of this common meta-language, such as the strategic orientation and the organizational culture, influences the dynamic features of the interaction, such as the inter-firm learning, the problem solving abilities, and the transfer abilities, by which the information exchange and knowledge configuration are implemented to create value. 


\section{Methods}

\section{The wine industry}

The hypotheses were tested by means of a cross-sectional survey of supplier relationships in the wine industry on the total number of Basilicata wineries.

Like some other studies on the subject (e.g. Dyer and Hatch 2006; Håkansson and Ford 2002), this study focuses on a single industry. This decision enhances internal validity, possibly at the expense of external validity.

Although the wine industry is not considered as characterized by a high presence of innovation (Fiore 2016), many wineries regularly develop their product, processes, and policies useful through innovative strategies, most of the time unconsciously, in order to procure a satisfactory answer to their market needs. In the wine sector, innovation processes focused mainly on promotion and marketing methods (Fiore 2016). Very often these two aspects are used in a coordinated way to sell products and structured trade policies (Dries et al. 2014).

The wine industry was chosen because of the importance of knowledge transfer and inter-firm learning for the process of searching for biodiversity, in particular in the upstream value-creating process.

The wine industry represents one of the most important sectors in southern Italy in terms of active companies, jobs, and revenues (Contò et al. 2015; Bigliardi and Galati 2013). In the wine sector, the majority of businesses are family-run and thus have structural problems with the quality of the company's internal management and skills.

The wine, however, is a set of territorial values and deeply rooted in local tradition and brings with it a series of relationships between companies which have their roots in time. As a result of innovation and market strategies of these, family businesses do not always follow paths of efficiency in relations with suppliers (Bresciani et al. 2016).

\section{Data collection and sample}

The paper presents an exploratory research as it seeks to provide evidence on the organizational and relational elements, within the dyadic relationship buyer-supplier, that affect the dynamic capabilities of grape growers and winemakers involved in biodiversity enhancing.

We analyze the wine supply network of the Basilicata region (in south eastern Italy): this case study is part of the wider research project named "Salbiovit," funded by Measure 124 of the RDP (Rural Development Program) Basilicata Region 2007-2013. The research project is related to the improvement of grape variety's genetic variability in the wine supply chain of Basilicata.

The unit of analysis for this research was the relationship between the winemaker, as a prime contractor, and a specific supplier, as nurseries. The relationship can be considered as a governance mode of transactions, having an impact on knowledge transfer in the supply chain (Amesse and Cohendet 2001), rather than a separate institution capable of learning (Selnes and Sallis 2003).

Our data were collected through a survey representing the whole population of winemakers and nurseries, under examination.

The population data was treated as a sample and supposed a hypothetical population, by making inferences in the usual method; as of this matter, so, we have essential data generating the "population" distribution. 
Questionnaires were organized in five sections: 1. The firm; 2. Market positioning; 3. Enterprise and strategic orientation; 4. Autological clone requirement analysis; and 5. Nursery chain analysis. Thirty-one different questions composed the survey. A prevalidation survey was administrated to a sample of five respondents (nursery experts, international wine entrepreneurs, eminent academic scholars, etc.) in order to identify and to select the variables to be investigated. Before the face-to-face interview, the questions were briefly presented. A trick control question was added for the reliability of the test responses (Oppenheimer et al. 2006).

The final dataset contains 29 responses over a series of variables (questions) related to organizational culture and strategic approach of respondents.

The interview was structured with questions both built with binary options and scaling responses; for these latter questions, seven Likert Scale items have been adopted (Not a priority; Low priority; Somewhat priority; Neutral; Moderate Priority; High priority; Essential priority), following Allen and Seaman (2007).

Within this research framework, it is hypothesized that the organizational culture (in terms of organizational structure, strategic orientation, flexibility degree, and management style) and the relational approach to the supplier have an influence on the knowledge transfer among the observed firms and on the related inter-firm learning and in turn, on the problem solving and transfer abilities in the dyadic buyer-supplier relationship.

\section{Measure validation}

The parameters characterizing the distributions of responses are shown in Table 1 in which, for each question, are highlighted:

- The distribution's normality (checked using the Shapiro-Wilk test);

- Mean $(\mu)$, standard deviation $(\sigma)$, median, mode, range, interquartile range, standard error of the mean (SEM), coefficient of variation (CV, or relative standard deviation-RSD);

- The summary box plots of the variables (on standardized values).

On the available data, an inferential statistics analysis was performed as follows:

a. Test of independence between variables (ANOVA for normal distribution, Kruskal-Wallis for non-normal distributions);

b. Principal Component Analysis (PCA), the applicability of which has been previously checked using Bartlett's and KMO tests, both positive. The analysis showed the principal components which account for about $70 \%$ of the total variability of the survey. The graph "principal component scatterplot" (made on the first two principal components) suggests any potential factors (that is, related groups of questions);

c. Correlation matrix, which shows for each pair of variables the correlation coefficient. The Spearman's rank correlation coefficient has been used being it more appropriate than the Pearson's correlation coefficient, due to non-normality of the distributions and the unverified linear relationship between variables. 
Table 1 Descriptive statistics: means, standard deviations, and correlations

\begin{tabular}{|c|c|c|c|c|c|c|c|c|c|}
\hline & $\begin{array}{l}\text { Normal } \\
\text { distrib. }\end{array}$ & a & $\sigma$ & median & $\min$ & $\max$ & $\begin{array}{l}\text { std error } \\
\mathrm{SE}=\sigma / \sqrt{m}\end{array}$ & $\begin{array}{l}\text { relative SE } \\
\mathrm{RSE}=\mathrm{SE} / \mu\end{array}$ & $\begin{array}{l}\text { var, coeff. } \\
\text { CV }= \\
\text { RSD }-\alpha / \mu\end{array}$ \\
\hline $016-1$ & No & 5.03445 & 6.981353 & 5. & 3. & 6. & 8.18223 & 0.03626 & 19.58 \\
\hline 016 & No & 3.75862 & 1.18488 & 4. & 1. & 6. & 0.22003 & 0.05854 & $31.5 \mathrm{z}$ \\
\hline D16_3 & No & $\begin{array}{l}4.44828 \\
5.17241\end{array}$ & $\begin{array}{l}1.37805 \\
1.03748\end{array}$ & 4. & 2 & $\begin{array}{l}7 . \\
6\end{array}$ & $\begin{array}{l}0.25590 \\
\theta 19265\end{array}$ & $\begin{array}{r}0.05753 \\
0.03725\end{array}$ & 31.08 \\
\hline $\begin{array}{l}\text { D16_4 } \\
\text { D16_5 }\end{array}$ & $\begin{array}{l}\text { No } \\
\text { No }\end{array}$ & $\begin{array}{l}3.12411 \\
4.03448\end{array}$ & $\begin{array}{l}1.03748 \\
8.865314\end{array}$ & $\begin{array}{l}5 . \\
4 .\end{array}$ & 2. & $\begin{array}{l}6 . \\
5 .\end{array}$ & $\begin{array}{l}0.19263 \\
8.16068\end{array}$ & $\begin{array}{l}0.03725 \\
0.03983\end{array}$ & $\begin{array}{l}21.18 \\
21.4 \mathrm{k}\end{array}$ \\
\hline 016 & No & 4.82759 & 1.69177 & 6. & 1. & 7. & $\begin{array}{l}.1 .31415 \\
8.3145\end{array}$ & 0.06587 & 35.08 \\
\hline D16_7 & No & 3.37931 & 1.34732 & 3. & & & 8.25819 & 0.07484 & 39.98 \\
\hline D16_ 8 & No & 5.62869 & Ө.828098 & 5. & 4. & 7. & 8.15227 & 0.82789 & $14.6 \%$ \\
\hline D16_9 & No & 4.62069 & 1.04928 & 4. & 2. & 6. & 8.19495 & 0.84217 & $22.7 \%$ \\
\hline D16_18 & No & 3.34493 & 6.813979 & 3. & 2. & 5. & 0. 15115 & 0.84519 & 24.38 \\
\hline D16_11 & No & 3.13793 & 6.693034 & 3. & 2. & 4. & 0.12869 & 0.94181 & 22.18 \\
\hline $\begin{array}{l}016-12 \\
016-13 \\
013\end{array}$ & $\begin{array}{l}\text { No } \\
\text { No }\end{array}$ & $\begin{array}{l}4.55621 \\
2.7931\end{array}$ & $\begin{array}{l}1.29667 \\
8.861034\end{array}$ & 5. & $\begin{array}{l}2 . \\
2\end{array}$ & $\begin{array}{l}6 . \\
4.9\end{array}$ & $\begin{array}{l}\theta .24867 \\
\theta .15999\end{array}$ & $\begin{array}{l}0.05248 \\
0.05724\end{array}$ & $\begin{array}{l}28.3 \% \\
38.88\end{array}$ \\
\hline 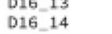 & $\begin{array}{l}\text { No } \\
\text { No }\end{array}$ & $\begin{array}{l}2.7931 \\
4.13793\end{array}$ & 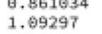 & 4. & $\begin{array}{l}2 . \\
2 .\end{array}$ & $\begin{array}{l}4 .- \\
6 .\end{array}$ & $\begin{array}{l}8.15989 \\
0.20296\end{array}$ & $\begin{array}{l}0.05724 \\
0.94905\end{array}$ & $\begin{array}{l}\frac{3}{33.88} \\
26.48\end{array}$ \\
\hline & No & 4.06897 & 9.961065 & 4. & 2. & 6. & 8.17847 & 0.84386 & 23.68 \\
\hline $016-16$ & No & 3.41379 & 8.866736 & 4. & 2. & 5. & в.16895 & 0.04715 & 25.48 \\
\hline 028 & No & 4,03448 & 1,76236 & 5. & 1. & 18. & 8. 32726 & 0.88112 & 43.78 \\
\hline 029 & No & 3.24138 & 1,57333 & 2. & 2. & 7. & 8.29216 & 0.69013 & 48,58 \\
\hline D36 & No & 3.06897 & 1,55681 & 2. & 2. & $7=$ & e. 28969 & 0.99428 & $58.7 \%$ \\
\hline $\begin{array}{l}031 \\
032\end{array}$ & No & $\begin{array}{l}5,41379 \\
5.596 ?\end{array}$ & $\begin{array}{l}1.18672 \\
1.49548\end{array}$ & 6. & 2. & 7 & $\begin{array}{l}\text { A. } 21925 \\
0.26899\end{array}$ & 0.94058 & 21,88 \\
\hline $\begin{array}{l}032-1 \\
032-2\end{array}$ & $\begin{array}{l}\text { No } \\
\text { No }\end{array}$ & $\begin{array}{l}5,75862 \\
4,41379\end{array}$ & $\begin{array}{l}1,48548 \\
2.09922\end{array}$ & $\begin{array}{l}6 . \\
6 .\end{array}$ & 0. & $\begin{array}{l}7 . \\
6 .\end{array}$ & $\begin{array}{l}\theta .26899 \\
\theta .37310\end{array}$ & $\begin{array}{l}8.04532 \\
0.98453 \\
0.943\end{array}$ & $\begin{array}{l}24.48 \\
45.58\end{array}$ \\
\hline $032-3$ & No & $\begin{array}{l}4.41379 \\
5.82759\end{array}$ & $\begin{array}{l}2,06922 \\
1.51349\end{array}$ & 7. & 2. & 7. & 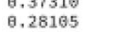 & $\begin{array}{l}0.08453 \\
0.94823\end{array}$ & 26.98 \\
\hline & No & 2.31834 & 8.712313 & 2. & $\theta$. & 3. & 8.13227 & 0.05725 & $30.8 \%$ \\
\hline D37 & No & в.286897 & $\theta .412251$ & ๑. & $\theta$. & 1. & В. 17655 & 0.37001 & 199.38 \\
\hline D48 & No & 3.96552 & 1.149 & 4. & 1. & 7. & 8. 21336 & 0.85386 & $29.0 \%$ \\
\hline 042 & No & 8. 0689655 & 8.371391 & $\theta$. & $\theta$. & 2. & ค. 16897 & 1. 80080 & $538.5 \%$ \\
\hline 043 & No & 0.286897 & 8.412251 & $\ominus$ & 0. & 1. & 0. 17655 & 0.37081 & 199,38 \\
\hline${ }_{0.45}^{044}$ & $\begin{array}{l}\text { No } \\
\text { No }\end{array}$ & $\begin{array}{l}10.3448 \\
1.03445\end{array}$ & $\begin{array}{l}7.31803 \\
8.185695 \\
8,1859\end{array}$ & 10. & 5. & 39. & $\begin{array}{l}1.35759 \\
8.93448\end{array}$ & $\begin{array}{l}0.13123 \\
0.03333\end{array}$ & 79.78 \\
\hline D46_a & No & $\begin{array}{l}1.832748 \\
5.82759\end{array}$ & $\begin{array}{l}0.1658405 \\
0.6585\end{array}$ & 6. & 5. & 7. & $\begin{array}{l}0.032226 \\
0.1226\end{array}$ & 0.02098 & $11.3 \%$ \\
\hline & & & & 6. & 5. & 7. & 0.12051 & 0.02105 & \\
\hline 046_a & No & 6.06897 & 0.457558 & 6. & 5. & 7. & 0.08497 & 0.01460 & $0.0 t$ \\
\hline D48_a & No & 5.27586 & 8.797162 & 5. & 3. & 7. & 0.14803 & 0.82806 & 15.18 \\
\hline D48_a & Nó & 5.03448 & 1.17967 & 5. & 2. & 6. & 8.21906 & 0.84351 & 23.48 \\
\hline D48_B & No & 5.37931 & 8.493804 & 5. & 5. & 6. & В. .99170 & 0.01705 & $0.6 \mathrm{z}$ \\
\hline D48_B & No & $\begin{array}{l}5.03448 \\
2.93103\end{array}$ & 8.56586 & 5. & 3. & 7. & $\begin{array}{l}0.10508 \\
0.22157\end{array}$ & 0.02087 & 11.28 \\
\hline $\begin{array}{l}\text { D48_a } \\
\text { D49 }\end{array}$ & $\begin{array}{l}\text { No } \\
\text { No }\end{array}$ & $\begin{array}{l}2.93103 \\
5.68966\end{array}$ & $\begin{array}{l}1.19317 \\
8.54139\end{array}$ & $\begin{array}{l}2 . \\
6 .\end{array}$ & $\begin{array}{l}2 . \\
5 .\end{array}$ & $\begin{array}{l}6 . \\
7 .\end{array}$ & $\begin{array}{l}8.22157 \\
8.10053\end{array}$ & $\begin{array}{l}0.07559 \\
0.01767\end{array}$ & $\begin{array}{l}40.78 \\
0.0 \%\end{array}$ \\
\hline D58 & No & $\begin{array}{l}3.58966 \\
5.58621\end{array}$ & $\begin{array}{l}8.627765 \\
8.625\end{array}$ & & & 7. & 8.11657 & 0.02087 & 11.28 \\
\hline D51_a & No & 5.58621 & 0.560032 & 6. & 5. & 7. & 0.10548 & $0.018 B \mathrm{~B}$ & 10.28 \\
\hline 051_a & No & 5.44328 & 0.50612 & 5. & 5. & 6. & 0. 09398 & 0.01725 & 0.08 \\
\hline D52_a & No & 5.86207 & 0.441114 & 6. & 5. & 7. & 0.๑8191 & 0.01397 & $0.0 \mathrm{t}$ \\
\hline D52_a & No & 5.7931 & 0.619968 & 6. & 4. & 7. & 0.11511 & 0.01987 & $10.7 \%$ \\
\hline D53_IFL_1 & No & 5.82759 & 0.75918 & 6. & 4. & 7. & $0.1409 \mathrm{~g}$ & 0.02419 & $13.0 \%$ \\
\hline D53-1FL 2 & No & $\begin{array}{l}4.82759 \\
5.13793\end{array}$ & a. 6399427 & 5. & 4. & $\begin{array}{l}6 . \\
6 . \\
6\end{array}$ & $\begin{array}{l}\theta .14698 \\
\theta .11874\end{array}$ & $\begin{array}{r}0.02928 \\
0.82311\end{array}$ & 15.78 \\
\hline D53_IFL_4 & No & 4.41379 & $\begin{array}{l}.0 .53423 \\
8.50123\end{array}$ & 4. & 4. & 5. & $\begin{array}{l}8.118174 \\
8.09308\end{array}$ & 0.82109 & $\begin{array}{l}11.48 \\
11.48\end{array}$ \\
\hline
\end{tabular}

In order to study the research questions, the PCA analysis showed that significant variables are as follow and are grouped into two categories: the first group is referred to the relational approach between the winery and grape grower, the strategic orientation of the wineries, and the organizational culture. The second one is referred to the grape grower's problem solving abilities, transfer abilities, and interfirm learning:

- The relational approach to the supplier (Håkansson and Ford 2002);

- The problem solving abilities (Håkansson and Ford 2002);

- The transfer abilities (Håkansson and Ford 2002);

- The strategic orientation (Narver and Slater 1990; Slater et al. 2006);

- The inter-firm learning (Kale et al. 2000);

- The organizational culture (Lawrence and Lorsch 1986; Morgan 2007).

\section{Predictive analysis}

Responses were analyzed by means of a data mining approach, being it the exploration and search for meaningful patterns and rule in data through suitable machine-learning algorithms that allows to extrapolate information from data that would be otherwise difficult to investigate being completely unknown and offers an indication of future trends based on what happened in the past. 
Within this framework, we hypothesized two "predictive" scenarios: organizational culture and strategic approach of respondents, clustering them into appropriate categories according to their responses.

\section{Results and discussions}

\section{The dynamic capabilities found}

The analysis of the issues concerning the research, the identification, and the enhancement of biodiversity with the surveyed entrepreneurs and managers showed clearly that the grape grower's dynamic capabilities which influences positively the service level to the winemakers; thus, their customer satisfaction and their capability to create distinctive value for their target market can be synthesized in the following elements:

- Knowledge of the soils: all entrepreneurs' and managers' survey highlighted that the main skill that distinguishes the grape growers, which lead them to choose the procurement of rooted cuttings, is the knowledge of the soils where their vineyards are planted. Such knowledge is not only related to the mere physical-chemical composition of the soil, while essential but also reproducible, but also to the climatic characteristics of the single plots of land where different types of cuttings have been grafted, during long periods of time. This type of knowledge arises from historic trusting winery-grape grower relationships, from a mastery of winegrowing needs in the observed area, from consolidated experience in the graft cuttings on those soils, and in the optimal growth of the plant. It is a very important competence since it determines the successful grafting of a new vineyard, in terms of yield, quality, and especially in terms of health of plants and vineyard (Antonazzo et al. 2014). It is a dynamic capability because over the years, the variables that regulate the graft choices and vineyard management are constantly changing: we refer, in particular, to the soil and climatic conditions, to the chemical-physical characteristics of the clones, and to the needs of the production processes, closely linked to the of market dynamics. It is an inimitable expertise because the thorough understanding of a territory you come from, the trusting (human before than business) relationships between grape grower and winemaker, allow the latter to receive a satisfactory service level from the grape grower, hard to get from non-local firm.

- Health guarantee of the rooted cuttings: closely linked to the first dynamic competence deriving from the knowledge of the soils, winemakers highlighted how the most important and crucial need for them is the certainty that the cutting they decide to graft be healthy and keep its wholesome condition during growth, so as not to undermine the investment in new plant and affecting the pre-existing vineyard.

- Continuous interventions into the vineyard to control grafted cuttings: the constant and frequent control of the grafts, combined with the in-depth knowledge of soils, represents the dynamic capability that procure more trust to winemakers about the healthiness of the cuttings and subsequent optimization of the winemaking process. Once again, geographical proximity plays a key role, in this case in logistic terms: it emerged, in fact, a remarkable level of dissatisfaction of wineries which engaged 
grape growers physically distant from the graft area caused by very rare check-ups, most of the times aimed at solving problems that have already emerged, rather than to anticipate them.

- High level of production flexibility: the adaptability of the grape growers' production processes (constitution and multiplication) is a strategic element for wineries since it allows them to be able to modify their production planning so as to better address their wines to the needs and preferences of the final markets, thus avoiding a negative financial impact on the balance of the company.

\section{The influential factors on dynamic capabilities for the research of biodiversity}

This overview of the dynamic capabilities required for research and enhancement of grape biodiversity lead us to the next research question: what influenced, in dyadic winery grape grower, the improvement of these skills?

During the interviews, entrepreneurs and managers have highlighted how the grape grower's resources and competences can be developed by an intense knowledge exchange within a lively and open business relationship: the in-depth analysis occurred during the interview revealed this knowledge exchange is influenced by factors both relational (the approach adopted in the report of supply) and firm-specific (such as the strategic direction and organizational culture).

The correlation matrix in Table 2 shows Pearson's Correlation values among different variables selected for testing the research questions.

Table 1 shows the descriptive statistics for the variables under study (including the control variables). Regarding the significance of the research design, findings confirm the main hypotheses on which this study was based upon.

The results show significant correlations between selected variables, some of which confirm the initial research hypothesis. The highest positive correlation values were found among:

- Relational approach to the suppliers-transfer abilities $\left(r=0.77 ;{ }^{* * *}\right)$

- Relational approach to the suppliers-problem solving abilities $\left(r=0.51 ;{ }^{* * *}\right)$

- Organizational culture-transfer abilities $(r=0.50 ; * *)$

- Organizational culture-problem solving abilities $(r=0.42 ; \%$ **

The significant positive correlation between the winery's relational approach to suppliers adopted toward the grape grower and the latter's transfer abilities and problem solving abilities confirms the Hp1.

This finding confirms what emerged during interviews with wine entrepreneurs and managers: the grape grower is able to develop better $(0.50 ; * *)$ its (problem solving) abilities in identifying and understanding the needs of the wine cellar (on the selection,

Table 2 Correlation analysis

\begin{tabular}{llll}
\hline & Problem solving abilities & Transfer abilities & Inter-firm learning \\
\hline Relational approach to the suppliers & $0.51\left(^{* * *}\right)$ & $0.77\left({ }^{* *}\right)$ & $0.00\left(^{* *}\right)$ \\
Strategic orientation & $0.00\left(^{*}\right)$ & $0.00\left(^{* *}\right)$ & $0.00\left(^{* *}\right)$ \\
Organizational culture & $0.42\left(^{* * *}\right)$ & $0.50\left({ }^{* *}\right)$ & $0.22\left(^{* *}\right)$ \\
\hline
\end{tabular}

*** significant at $99 \% ;{ }^{* *}$ significant at $95 \% ;{ }^{*}$ significant at $90 \%$ 
constitution and multiplication of the desired clones), in turning in their offer (rooted cuttings to graft) in a short time, and conveying (transfer ability -0.77 ; ***) new useful information for the winery (graft feasibility of a new clone, possible yield, the germplasm's features), with wineries that show a relational approach to the grape-grower supplier mainly strategic, rather than a mere buying approach.

This type of strategic approach comes up from sharing of product development strategies with the grape grower that means sharing of several kinds of problems such as commercial, project, technological, and product industrialization in order to accelerate and enhance the introduction of new wines into the market.

This strategic approach to supplies is also highlighted by a focus on stable and deep relationships with few suppliers, so typical of companies that adopt a single sourcing strategy. We did not find, however, a significantly positive correlation between the strategic relational approach and the inter-firm learning.

The $\mathrm{Hp} 4$ and 5 are also confirmed by the significant correlation between problem solving abilities and transfer abilities of the grape grower with the organizational culture.

In particular, it appears that a business culture based on organizational flexibility characterized by technologies that generate tasks with responsibility and extended autonomy and non-standard transformation processes, has a positive effect on problem solving abilities $\left(0.42 ;{ }^{* * *}\right)$.

Moreover, the grape-grower transfer abilities develop more easily $(0.51 ; * *)$ in relationships with customers whose employees have an appropriate degree of autonomy to be able to make decisions quickly and whose operational and control processes must follow agreed stable procedures.

The organizational culture variable does not show any significant correlation with the inter-firm learning, thus not confirming the $\mathrm{Hp} 3$.

The Hp 2, according to which the strategic orientation, meant as the common language and shared usual behavior that facilitate the interaction, can positively affect the inter-firm learning, is not confirmed by the absence of significant correlations.

By the analysis of the opinions and explanations of the managers and entrepreneurs already interviewed, it emerged that those wineries that pay high attention to their target market sensorial needs (that means wineries strongly customer-oriented) have a better and deeper technical knowledge of the chemical-physical characteristics their grape variety must have; thus, they are able to transfer clearly and effectively this knowledge to their grape grower supplier: in this way, the latter is highly facilitated in every stage of its own value-creating process that are research and development, clonal selection, and grapevine growing.

It also affects positively the grape growers' abilities to transfer new knowledge about new clones learned in the experimental stage to the wineries, which can, in this way, increase their skills and competences.

On the other hand, concerning the wineries strongly competitor-oriented, the analysis found fewer effectiveness in the inter-firm learning: according to the managers' opinion analysis, that is because the competitive efforts, targeted to understand with the competitors product policies, focus on existing varieties, on innovative winemaking methods they have adopted. 
This result is in line with previous studies that highlight the opportunities for growth in this sector and are subject to the companies' ability to upgrade products and differentiate supplies (Galati et al. 2014; Borsellino et al. 2012); in addition, in order to better remunerate the grapes and encourage a high-quality production, wineries and nurseries should open to a greater market orientation enhancing production and closing the wine production chain (Galati et al. 2015).

\section{Conclusions}

The search for competitive advantage through product differentiation is a strategy that implies for the winemakers to convey the efforts in the interaction with the actors in the upstream phase of the wine industry through research and enhancement of biodiversity that can be crucial for the wine market (Pinder 2011). The dynamic capabilities required in this process through the analysis of the dyadic interaction between wineries and grape growers of the population of wine industry of Basilicata region are attributable to the in-depth knowledge of the soils and plots: in these, latter new clones have to be grafted to the guarantee of cuttings' health, to the continuous field control intervention on the vineyard, and to a high level of production flexibility by the grape growers.

Empirical surveys were carried out through in-depth interviews with business owners and managers of the observed farms, highlighted how the abovementioned grape growers' dynamic capabilities are enhanced within the dyadic buyer-supplier interaction with winemakers and may be influenced by factors both relational and firmspecific. This is in line with the literature on the topic (Fiocca 2014; Prahalad and Hamel 1990).

Data analysis showed how a strategic approach adopted by the winery in the relationship with the grape grower affects positively the latter's problem solving and transfer abilities (meant as the ability to offer quickly solutions to the technical requirements of winemakers and to convey any new information on the graft on a new clone, useful for the winery), thus increasing the dynamic core competencies related to the soil's knowledge and to the rooted cutting health assurance.

It emerges also how the transfer and problem solving abilities of the grape grower are positively influenced by an organizational culture of winemakers based on flexibility and transformation processes which are not standardized, since these elements facilitate the planting choices, thereby helping the grape grower in its production planning and in assuring the health of cuttings.

The follow-up study conducted with stakeholders to discuss the insights collected in the first round of interviews suggests that the above highlighted significant correlations positively influence the research and development of a new clone and the effective engagement in the vineyard, as it helps to predict their possible problems on field and later in the process; therefore, it affects the configuration process knowledge, fundamental in the development of the dynamic capabilities.

The hypothesis that the inter-organizational learning was positively influenced by the strategic orientation of wineries and by the characteristics of their organizational culture have not been confirmed in the analysis of correlation.

The deepening with the observed actors allowed us to understand how new knowledge (one of observed variables to analyze the IFL) the winery learns from grape 
growers are mainly related to the correct management of the plant in the vineyard, aimed at an optimal yield of the clone in organoleptic terms, but it is not a constant but rare learning.

Implications for managers and entrepreneurs are on the crucial role of the relational and firm-specific factors such as the relational approach to the supplier and the winery's strategic orientation more than integrating new knowledge of clones for subsequent reconfiguration useful to improve knowledge of the soil and new grafts on it.

Overall, the research has reached a number of conclusions that both stress the need to extend and improve the organizational culture of winemakers based on flexibility so by easing the planting choices and assuring the health of cuttings.

Further studies should focus on the motivations and the main determinants that can push grape growers to learn from grape growers in order to reach an optimal yield of the clone in organoleptic terms. Furthermore, it could be interesting to carry out an EU crossnational and/or an Italian cross-regional comparison of wine and nursery sector actors.

Availability of data and materials

The data that support the findings of this study can be obtained from the authors based on request.

Authors' contributions

FC conceptualized and coordinated the study. RS designed and supervised the survey. PLS was responsible for performing the data analysis and was responsible for the interpretation of the model results and write up of the manuscript. All the authors read and approved the final manuscript.

\section{Authors' information}

Piermichele La Sala has a researcher position in Agricultural Economics at the University of Foggia, Department of Economics. His main research interests are Rural and Local Development, Agrarian and Food Policies, Agricultural Extension Services, Innovation, and knowledge in agriculture.

Raffaele Silvestri is an adjunct professor of Business Management at the University of Bari A. Moro. He developed also significant professional experience in logistics and marketing in multinational companies and small businesses. Francesco Contò is a full professor and he is Director of the Department of Economics, University of Foggia (Italy). His main research interests are rural development and multifunctionality, Information and Communication Technologies in Agriculture, Food, Health and Environment.

Ethics approval and consent to participate

Ethical approval and consent to participate is not applicable for our study.

Competing interests

The authors declare that they have no competing interests.

\section{Publisher's Note}

Springer Nature remains neutral with regard to jurisdictional claims in published maps and institutional affiliations.

\section{Author details}

${ }^{1}$ Department of Economics, University of Foggia, Largo Papa Giovanni Paolo II n. 1, 71122 Foggia, Italy. ${ }^{2}$ Department of Economic Science, University of Bari, Largo Abbazia Santa Scolastica 53, 70124 Bari, Italy.

Received: 8 April 2017 Accepted: 6 October 2017

Published online: 01 December 2017

\section{References}

Allen E, Seaman C (2007) Likert scales and data analyses. Qual Prog 40(7):64-65

Amesse F, Cohendet P (2001) Technology transfer revisited from the perspective of the knowledge-based economy. Res Policy 30(9):1459-1478

Antonazzo AP, Fiore M, La Sala P, Contò F (2014) Assessing perceptions of wine tourists on organic wine. Economia Agro-Alimentare 2:57-76

Augusto M, Coelho F (2009) Market orientation and new-to-the-world products: exploring the moderating effects of innovativeness, competitive strength, and environmental forces. Ind Mark Manag 38(1):94-108

Barile S (2009) Management sistemico vitale. Giappichelli, Torino

Barney JB (1991) Firm resources and sustained competitive advantage. J Manag 17(1):99-120

Bigliardi B, Galati F (2013) Innovation trends in the food industry: the case of functional foods. Trends Food Sci Technol $31(2): 118-129$

Borsellino V, Galati A, Schimmenti E (2012) Survey on the innovation in the Sicilian grapevine nurseries. Journal of Wine Research 23(1):1-13 
Bresciani S, Giacosa E, Broccardo L, Culasso F (2016) The family variable in the French and Italian wine sector. EuroMed Journal of Business 11(1):101-118

Cafaggi F, lamiceli P (2010) Inter-firm networks in the European wine industry. Available at: http://cadmus.eui.eu/ handle/1814/15654. Accessed 16 Mar 2017

Camuffo A, Grandinetti R (2011) I distretti industriali come sistemi locali di innovazione. Sinergie rivista di studi e ricerche 69(1):33-60

Cantù C, Corsaro D, Fiocca R, Tunisini A (2013) IMP studies: a bridge between tradition and innovation. Ind Mark Manag 42(7):1007-1016

Carbone A (2017) Food supply chains: coordination governance and other shaping forces. Agricultural and Food Economics 5:3

Celuch KG, Kasouf CJ, Peruvemba V (2002) The effects of perceived market and learning orientation on assessed organizational capabilities. Ind Mark Manag 31(6):545-554

Cembalo L (2015) Innovation and valorization in supply chain network. Agricultural and Food Economics 3:5

Contò F, Fiore M, Vrontis D, Silvestri R (2015) Innovative marketing behaviour determinants in wine SMEs: the case of an Italian wine region. Int. J. Glob. Small Bus. 7(2):107-124

Contò F, Santini C, La Sala P, Fiore M (2016) Reducing information gap and increasing market orientation in the agribusiness sector: some evidences from Apulia region, recent patents on food. Nutrition \& Agriculture 8(1):48-54

Conto F, Vrontis D, Fiore M, Thrassou A (2014) Strengthening regional identities and culture through wine industry cross border collaboration. Br Food J 116(11):1788-1807

Denison DR, Spreitzer GM (1991) Organizational culture and organizational development: a competing values approach. Research in organizational change and. Development 5:1-21

Dries L, Pascucci S, Török Á, Tóth J (2014) Keeping your secrets public? Open versus closed innovation processes in the Hungarian wine sector. International food and agribusiness. Manag Rev 17(1):147-162

Dyer JH, Hatch NW (2004) Using supplier networks to learn faster. Sloan Manag Rev 45(3):57-63

Dyer JH, Hatch NW (2006) Relation-specific capabilities and barriers to knowledge transfers: creating advantage through network relationships. Strateg Manag J 27(8):701-719

Festa G, Vrontis D, Thrassou A, Ciasullo A (2015) A value co-creation model for wine industry. International Journal Management Practice 8(3):247-267

Fiocca R (2014) Impresa futura. Nuove prospettive per l'impresa e il management del domani: Nuove prospettive per l'impresa e il management del domani. FrancoAngeli, Milan

Fiore M (2016) Direct selling in the wine sector: lessons from cellars in Italy's Apulia region. Br Food J 118(8):1946-1959

Fiore M, Silvestri R, Contò F, Pellegrini G (2017) Understanding the relationship between green approach and marketing innovations tools in the wine sector. J Clean Prod 142:4085-4091

Fuentes-Lombardo G, Fernandez-Ortiz R, Cano-Rubio M (2014) Intangible assets in the internationalization of Spanish wineries: directive and compared perception between family and non family businesses. Intangible Capital 7(2):428-473

Galati A, Borsellino V, Crescimanno M, Pisano G, Schimmenti E (2015) Implementation of green harvesting in the Sicilian wine industry: effects on the cooperative system. Wine Economics and Policy 4(1):45-52

Galati, A., Crescimanno,M., Rossi, M., Farruggia, D., Tinenvia, S. (2014) The determinants affecting the internationalization of the Italian SMEs producing sparkling wines: an empirical study on the RBV of the firms. Int J Glob Small Bus 6(2),100-118

Georgiou T, Vrontis D (2013) Wine sector development: conceptual framework towards succession effectiveness in family wineries. Journal of Transnational Management 18(4):246-272

Grant RM (1996) Toward a knowledge-based theory of the firm. Strateg Manag J 17:109-122

Gregory BT, Harris SG, Armenakis AA, Shook CL (2009) Organizational culture and effectiveness: a study of values, attitudes, and organizational outcomes. J Bus Res 62(7):673-679

Håkansson H, Ford D (2002) How should companies interact in business networks? J Bus Res 55(2):133-139

Hult GT, Ketchen JDJ, Slater SF (2004) Information processing, knowledge development and strategic supply chain performance. Acad Manag J 47(2):241-253

Hurley RF, Hult GTM (1998) Innovation, market orientation, and organizational learning: an integration and empirical examination. J Mark 62(3):42-54

Inkpen AC (2000) Learning through joint ventures: a framework of knowledge acquisition. J Manag Stud 37(7):1019-1043

Itami H, Roehl T (1987) Mobilizing intangible assets. Harvard University Press, Cambridge (Mass.)

Kale P, Singh H, Perlmutter H (2000) Learning and protection of proprietary assets in strategic alliances: building relational capital. Strateg Manag J 21(3):217-237

Kanter RM (1994) Collaborative advantage: successful partnerships manage the relationship, not just the deal. Harv Bus Rev 72:96-108

Khin S, Ahmad NH, Ramayah T (2012) The integrated effect of strategic orientations on product innovativeness: moderating role of strategic flexibility. In: Procedia-Social and Behavioral Sciences, International Congress on Interdisciplinary Business and Social Sciences 2012 (ICIBSOS 2012), 3 December 2012, vol 65, pp 743-748

Kohli AK, Jaworski BJ (1990) Market orientation: the construct, research propositions, and managerial implications. J Mark 54(2):1-18

Laskowska-Rutkowska A (2009) The impact of national and organizational culture on the cooperation of firms-a supply chain perspective. J Int Manag 1(2):5-16

Lawrence PR, Lorsch JW (1986) Organization and environment: managing differentiation and integration (Harvard Business School Classics)

Leonard Barton D (1992) Core capabilities and core rigidities: a paradox in managing new product development. Strateg Manag J 32(11):1243-1250

Modi SB, Mabert VA (2007) Supplier development: improving supplier performance through knowledge transfer. J Oper Manag 25(1):42-64

Morgan G (2007) Imrages. Le metafore dell'organizzazione, vol 8. FrancoAngeli, Milan

Narver JC, Slater SF (1990) The effect of a market orientation on business profitability. J Mark 54(4):20-35

Noorderhaven NG, Koen Cl, Beugelsdijk S (2002) Organizational culture and network embeddedness. Tilburg University, Tilburg

Oppenheimer DA, Meyvis T, Davidenko N (2006) Instructional manipulation checks: detecting satisfying to increase statistical power. J Exp Soc Psychol 45:867-872

Paladino A (2007) Investigating the drivers of innovation and new product success: a comparison of strategic orientations. Product Innovation Management 24(6):534 
Pinder RM (2011) Biodiversity of wine grapes: less than we thought. International Journal of Wine Research 3(1):19-20 Prahalad CK, Hamel G (1990) The core competence of the corporation. Harv Bus Rev 67:79-91

Revoredo-Giha C, Renwick A (2016) Market structure and coherence of international cooperation: the case of the dairy sector in Malawi. Agricultural and Food Economics 4:8

Rossi M, Vrontis D, Thrassou A (2012) Wine business in a changing competitive environment-strategic and financial choices of Campania wine firms. International Journal of Business and Globalisation 8(1):112-130

Selnes F, Sallis J (2003) Promoting relationship learning. J Mark 67(2):80-95

Silvestri R, Santovito S, La Sala P, Contò F (2016) Which strategic orientation for systemic integration? A study on the organic olive oil industry. Int J Applied Systemic Studies 6(3):223-238

Simonin BL (2004) An empirical investigation of the process of knowledge transfer in international strategic alliances. J Int Bus Stud 35(5):407-427

Slater SF, Olson EM, Hult GTM (2006) Research notes and commentaries the moderatine influence of strategic orientation on the strategy formation capability performance relationship. Strateg Manag J 27(12):1221-1231

Spekman RE, Spear J, Kamauff JW (2002) Supply chain competency: learning as a key component. Supply Chain Management: An International Journal 7(1):41-55

Stoddard JE, Clopton SW (2015) Exploring the differences between new and repeat visitors to North Carolina wineries: implications for winery marketing strategy development. Journal of Wine Research 26(3):225-240

Teece DJ, Pisano G, Shuen A (1997) Dynamic capabilities and strategic management. Strateg Manag J 18(7):509-533

Theoharakis V, Hooley G (2008) Customer orientation and innovativeness: differing roles in new and old Europe. Int J Res Mark 25(1):69-79

Tudisca S, Di Trapani AM, Sgroi F, Testa R (2013) Marketing strategies for mediterranean wineries competitiveness the case of Pantelleria. Quality - Access to Success 14(137):101-106

Verona G (2014) Le competenze dinamiche a supporto dell'imprenditorialità aziendale: analisi di un caso visibile di discontinuità tecnologica. Sinergie. Quaderni 17:161-174

Viassone M, Vrontis D, Papasolomou I (2016) The relationship between wine sector and regional competitiveness. Global Business and Economics Review 18(3/4):259-276

Vrontis D, Bresciani S, Giacosa E (2016) Tradition and innovation in Italian wine family businesses. Br Food J 18(8):1883-1897

Vrontis D, Papasolomou I (2007) Brand and product building: the case of the Cyprus wine industry. J Prod Brand Manag 16(2-3):159-167

Vrontis D, Thrassou A, Czinkota MR (2011) Wine marketing: a framework for consumer-centred planning. J Brand Manag 18(4/5):245-263

Wagner SM, Buko C (2005) An empirical investigation of knowledge-sharing in networks. J Supply Chain Manag 41(4): $17-31$

Wang X, Li JZ (2007) Innovation network in harvest. In: Proceedings of the first international conference on technology innovation, risk management and supply chain management, 1-2). pp. 420-424

Xiao Z, Tsui AS (2007) When brokers may not work: the cultural contingency of social capital in Chinese high-tech firms. Adm Sci Q 52:1-31

Xiaoming C, Junchen H (2012) A literature review on organization culture and corporate performance. International Journal of Business Administration 3(2):28-37

Zheng Y, Yang B, McLean GN (2010) Linking organizational culture, structure, strategy, and organizational effectiveness: mediating role of knowledge management. J Bus Res 63:763-771

\section{Submit your manuscript to a SpringerOpen ${ }^{\circ}$ journal and benefit from:}

- Convenient online submission

- Rigorous peer review

Open access: articles freely available online

- High visibility within the field

Retaining the copyright to your article 